\title{
ANALISIS KEMAMPUAN METAKOGNITIF SISWA DALAM MENYELESAIKAN MASALAH MATEMATIKA DI SMP NEGERI 4 BENDAHARA ACEH TAMIANG
}

\author{
Nurdiana Fahmi ${ }^{1}$, Bornok Sinaga ${ }^{2}$, W. Rajagukguk ${ }^{3}$
}

\begin{abstract}
ABSTRAK
Penelitian ini bertujuan untuk menganalisis: 1) kemampuan metakognitif siswa dalam menyelesaikan masalah, 2) jenis-jenis kesulitan siswa dalam menyelesaikan masalah matematika, 3) proses jawaban siswa dalam menyelesaikan masalah matematika. Penelitian ini merupakan penelitian kualitatif deskriptif yang bertujuan untuk menganalisis kemampuan metakognitif siswa dalam menyelesaikan masalah matematika dengan pembelajaran berbasis masalah. subjek dalam penelitian ini adalah siswa kelas VII SMP Negeri 4 Bendahara Aceh Tamiang. Subjek yang dikenai wawancara mendalam terdiri dari 4 kategori yaitu : satu orang siswa dengan kemampuan tinggi, satu orang siswa dengan kemampuan sedang, satu orang siswa dengan kemampuan rendah dan satu orang siswa dengan banyak kesalahan. Data diperoleh dari tes yang diberikan dalam bentuk essay dan wawancara yang mendalam. Objek dalam penelitian ini adalah kemampuan metakognitif siswa dalam menyelesaikan masalah matematika pada pembelajaran berbasis masalah pada materi penerapan konsep operasi hitung bilangan bulat dan pecahan dalam menyelesaikan masalah sehari-hari.berdasarkan analisis data diperoleh bahwa : 1) Siswa dengan kemampuan penyelesaian masalah tinggi memiliki tingkat kemampuan metakognitif Strategic Use, siswa dengan kemampuan sedang memilikitingkat metakognitif Aware Use, dan siswa dengan kemampuan rendah memiliki kemampuan metakognitif Tacit Use. 2) jenis kesulitan yang dialami siswa dalam menyelesaikan masalah matematika berdasarkan kesulitan fakta, konsep, prinsip dan prosedur.
\end{abstract}

Kata Kunci: Analisis, Kemampuan Metakognitif, Pemecahan Masalah, Problem Based Learning

\section{PENDAHULUAN}

Pendidikan sebagai salah satu sektor yang sangat berperan penting, diharapkan mampu menjadi sarana yang potensial dan strategi dalam upaya mencerdaskan kehidupan bangsa dan mengembangkan manusia Indonesia seutuhnya, serta membentuk tenaga yang produktif dan memiliki daya saing tinggi.

Masalah pendidikan senantiasa menjadi topik perbincangan yang menarik dikalangan masyarakat luas, lebih lagi bagi insan pendidikan, sebab hingga saat kini dunia pendidikan dipandang sebagai sarana yang efektif dalam usaha melestarikan nilai-nilai hidup. Salah satu pendidikan yang dapat dilakukan adalah pendidikan di sekolah mulai dari pendidikan dasar, pendidikan menengah hingga pendidikan tinggi dengan segala aspeknya, kurikulum, metode, pendekatan, strategi dan model yang sesuai, fasilitas yang memadai dan sumber daya manusia yang professional adalah aspek yang saling berkaitan untuk mencapai tujuan yang direncanakan.

${ }^{I}$ Corresponding Author: Nurdiana Fahmi

Program Magister Pendidikan Matematika, Universitas Negeri Medan, Medan, 20221, Indonesia

E-mail:dhyanfahmi58@gmail.com

${ }^{2}$ Co-Author: Bornok Sinaga \& W. Rajagukguk

Program Studi Pendidikan Matematika, Universitas Negeri Medan, Medan, 20221, Indonesia
Salah satu masalah besar dalam bidang pendidikan di Indonesia yang banyak diperbincangkan adalah rendahnya mutu pendidikan. Rendahnya mutu pendidikan dibuktikan dengan nilai ujian nasional yang kurang memuaskan setiap tahunnya.

Berbagai upaya dilakukan untuk meningkatkan kualitas pendidikan terus, mulai dari berbagai pelatihan untuk peningkatan kualitas guru, penyempurnaan kurikulum secara periodik, perbaikan sarana dan prasarana sampai dengan peningkatan manajemen sekolah. Namun pada kenyataan, hasil belajar siswa untuk mata pelajaran tertentu ternyata kurang menggembirakan termasuk salah satunya pada mata pelajaran matematika. Matematika merupakan salah satu mata pelajaran yang penting untuk dipelajari. Mulai kita kecil, Sekolah Dasar (SD), Sekolah Menengah Pertama (SMP) dan Sekolah Menengah Atas (SMA). Matematika seolah-olah menjadi mata pelajaran yang wajib. Banyak aktivitas yang dilakukan manusia berhubungan dengan matematika, contohnya menghitung ongkos bus, berbelanja, berjualan, dan lain-lain.

Sebagaimana diungkapkan Chairani (2016) bahwa matematika merupakan ilmu universal yang mendasari perkembangan, mempunyai peranan penting dalam berbagai disiplin dan memajukan daya pikir manusia. Kebanyakansiswa selalu beranggapan bahwa 
matematika itu sulit, penuh dengan rumusrumus sertamembosankan. Selain faktor itu, ada faktor lain yang membuat siswa merasa bosan dan kurang tertarik dalam belajar matematika. Salah satunya yaitu model atau metode yang digunakan guru dalam proses pembelajaran, model konvensional yang sering digunakan akan berdampak negatif.

Ada 5 tujuan pelajaran matematika di dalam National Council of Teacher of Mathematics ( NCTM, 2000 : 28) terdapat 5 aspek keterampilan matematik (doing math) yaitu : (1) belajar untuk berkomunikasi (mathematical communication); (2) belajar untuk bernalar (mathematical reasoning); (3) belajar untuk memecahkan masalah (mathematical problem solving); (4) belajar untuk mengaitkan ide (mathematical conections); (5) pembentukan sikap positif terhadap matematika (positive attitudes toward mathematics). Sinaga dalam jurnalnya "Development of Learning Devices Through Problem Based Learning Model to Improve Student Metacognition Skill" menyatakan bahwa keterampilan metakognisi melibatkan pengetahuan dan kemampuan kognitif seseorang.

Kemampuan metakognitif dianggap perlu dimiliki siswa dalam menyelesaikan masalah. Mengajar dengan menyajikan melalui masalahmasalah memberikan kesempatan kepada siswa untuk membangun konsep matematika dan mengembangkan keterampilan matematikanya. Sejalan dengan penelitian yang dilakukan oleh Barbacena (2015) menyatakan bahwa “ Problem solving merging the thinking skills and metacognitive functions for better performance in mathematics". Yang artinya pemecahan masalah menggabungkan keterampilan berpikir dan fungsi metakognitif untuk kinerja yang lebih baik dalam matematika.

\section{METODE PENELITIAN}

Jenis penelitian ini adalah penelitian deskriptif dengan pendekatan kualitatif. Menurut Moleong (2009:6) bahwa "penelitian kualitatif adalah penelitian yang bermaksud untuk memahami fenomena apa saja yang dialami oleh subjek penelitian. Misalnya perilaku, persepsi, motivasi, tindakan, dan lainlain. Secara holistik dan dengan cara deskripsi dengan memanfaatkan metode alamiah".

Penelitian ini akan dilaksanakan di SMP Negeri 4 Bendahara yang pelaksanaannya berlangsung pada semester ganjil tahun pelajaran 2018/2019. Dilaksanakan selama 4 kali pertemuan. Subjek dalam penelitian ini adalah siswa kelas VII-2 SMP Negeri 4 Bendahara kecamatan Banda Mulia Kabupaten
Aceh Tamiang tahun Ajaran 2018/2019, yang pada proses pembelajarannya menerapkan model Problem Based Learning dengan jumlah 25 siswa. Objek dalam penelitian ini adalah kemampuan metakognitif siswa dalam menyelesaikan masalah matematika pada materi Bilangan bulat dan pecahan.

Proses keterampilan metakognitif siswa dianalisis dengan menggunakan pendekatan data kualitatif model Miles dan Huberman. Skor setiap peserta tes ditentukan berdasarkan hasil tes; semua lembar jawaban siswa dari hasil tes metakognitif siswa dikumpulkan untuk dinilai dan dinilai. Skor untuk jawaban masing-masing siswa didasarkan pada pedoman penilaian keterampilan Metakognitif siswa, dan kemudian skor dikategorikan sesuai dengan kategori yang digunakan di sekolah.

\section{PEMBAHASAN HASIL PENELITIAN}

Tujuan dari penelitian ini adalah diperolehnya informasi tentang pembelajaran matematika dengan menanamkan kesadaran individu yang aktif dan memiliki kesadaran berfikir tenteng pengetahuan yang dimiliki siswa dalam menyelesaikan masalah matematika melalui model pembelajaran Problem Based Learning (PBL).

Tabel 1. Hasil Kemampuan Metakognitif

\begin{tabular}{clcc}
\hline No & $\begin{array}{c}\text { Tingkat } \\
\text { Metakognitif }\end{array}$ & $\begin{array}{c}\text { Jumlah } \\
\text { siswa }\end{array}$ & $\begin{array}{c}\text { Perse } \\
\text { ntase }\end{array}$ \\
\hline 1. & Reflective Use & 1 & $4 \%$ \\
\hline 2. & Strategic Use & 5 & $20 \%$ \\
\hline 3. & Aware Use & 10 & $40 \%$ \\
\hline 4. & Tacit Use & 9 & $36 \%$ \\
\hline
\end{tabular}

Dari tabel diatas memperlihatkan gambaran umum secara kuantitatif tingkat kemampuan metakognitif siswa dalam menyelesaikan masalah matematika. Pada tabel tersebut terlihat secara keseluruhan bahwa kemampuan metakognitif siswa paling banyak berada pada tingkat Aware Use. Dengan demikian dapat disimpulkan bahwa siswa hanya memenuhi 2 dari 3 tahapan pada kemampuan metakognitif siswa. Dimana, pada indikator pemantauan siswa menyadari kesalahan namun tidak ada upaya untuk memperbaiki.

Jika disajikan dalam bentuk diagram sebagai berikut: 


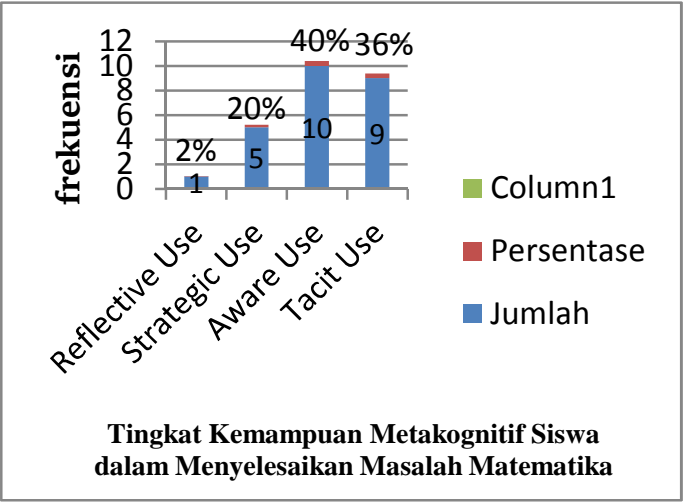

Gambar 1. Diagram Tingkat Kemampuan Metakognitif Siswa

Berdasarkan diagram diatas, siswa yang memiliki kemampuan metakognitif dengan tingkat reflective Use sebanyak 1 siswa dengan persentase $2 \%$. Dari selisih persentase diperoleh bahwa sedikit sekali siswa yang mampu memenuhi indikator pada setiap tahapan kemampuan metakognitif, baik pada tahap perencanaa, pemantauan maupun penilaian.

Untuk siswa berkemampuan tinggi menyatakan bahwa dengan pembelajaran berkelompok dengan menggunakan Problem based learning lebih menarik sehingga hasil tes tertulis dalam menyelesaikan masalah sudah dikerjakan dengan baik

Tabel 2. Kemampuan Metakognitif Siswa Berkemampuan Tinggi

\begin{tabular}{|c|c|c|}
\hline $\begin{array}{c}\text { No } \\
\text { Soal }\end{array}$ & $\begin{array}{l}\text { Kriteria Aspek } \\
\text { Pencapaian } \\
\text { Indikator }\end{array}$ & $\begin{array}{c}\text { Tingkat } \\
\text { Metakognitif }\end{array}$ \\
\hline 1 & $\begin{array}{l}\text { Menjelaskan materi } \\
\text { prasyarat dalam } \\
\text { menyelesaikan } \\
\text { masalah dengan } \\
\text { tepat namun tidak } \\
\text { lengkap. }\end{array}$ & Strategic Use \\
\hline 2 & 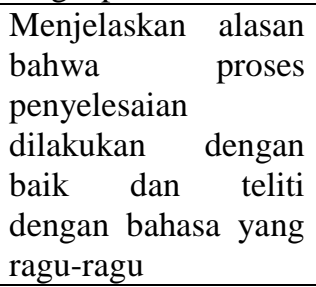 & Strategic Use \\
\hline 3 & $\begin{array}{l}\text { Menjelaskan materi } \\
\text { prasyarat dalam } \\
\text { menyelesaikan } \\
\text { masalah dengan } \\
\text { tepat dan lengkap. }\end{array}$ & Strategic Use \\
\hline 4 & $\begin{array}{l}\text { Menjelaskan materi } \\
\text { prasyarat dalam } \\
\text { menyelesaikan } \\
\text { masalah dengan } \\
\text { tepat dan lengkap. }\end{array}$ & Strategic Use \\
\hline
\end{tabular}

Untuk siswa berkemampuan sedang menyatakan bahwa pembelajaran dengan berkelompok menyenangkan karena memiliki teman berdiskusi saat mengerjakan permasalahan yang diberikan sehingga hasil tes tertulis dalam menyelesaikan masalah sudah dikerjakan dengan baik meski kurang lengkap

Tabel 3. Kemampuan Metakognitif Siswa Berkemampuan Sedang

\begin{tabular}{|c|c|c|}
\hline $\begin{array}{c}\text { No } \\
\text { Soal }\end{array}$ & $\begin{array}{l}\text { Kriteria Aspek } \\
\text { Pencapaian } \\
\text { Indikator }\end{array}$ & $\begin{array}{c}\text { Tingkat } \\
\text { Metakognitif }\end{array}$ \\
\hline 1 & $\begin{array}{l}\text { Menjelaskan strategi } \\
\text { penyelesaian } \\
\text { masalah yang akan } \\
\text { digunakan dengan } \\
\text { tidak tepat dan tidak } \\
\text { lengkap }\end{array}$ & Aware Use \\
\hline 2 & $\begin{array}{l}\text { Menjelaskan strategi } \\
\text { penyelesaian } \\
\text { masalah yang akan } \\
\text { digunakan dengan } \\
\text { tepat namun tidak } \\
\text { lengkap. }\end{array}$ & Strategic Use \\
\hline 3 & $\begin{array}{l}\text { Menjelaskan } \\
\text { informasi yang } \\
\text { penting diingat } \\
\text { dalam } \\
\text { menyelesaikan } \\
\text { masalah dengan } \\
\text { tepat namum tidak } \\
\text { lengkap }\end{array}$ & Strategic Use \\
\hline 4 & $\begin{array}{l}\text { Menjelaskan konsep } \\
\text { materi yang akan } \\
\text { digunakan dengan } \\
\text { tepat namun tidak } \\
\text { lengkap }\end{array}$ & Aware Use \\
\hline
\end{tabular}

Untuk siswa berkemampuan rendah menyatakan kurang menyukai pembelajaran dimana siswa terlebih dahulu menyelesaikan masalah yang diberikan, siswa berkemampuan rendah lebih menyukai bila guru mejelaskan pelajaran secara rinci lalu melatih mereka mengerjakan soal.

Tabel 4. Kemampuan Metakognitif Siswa Berkemampuan Rendah

\begin{tabular}{cll}
\hline $\begin{array}{c}\text { No } \\
\text { Soal }\end{array}$ & $\begin{array}{c}\text { Kriteria Aspek } \\
\text { Pencapaian } \\
\text { Indikator }\end{array}$ & $\begin{array}{c}\text { Tingkat } \\
\text { Metakognitif }\end{array}$ \\
\hline 1 & $\begin{array}{l}\text { Menjelaskan } \\
\text { alasan proses } \\
\text { penyelesaian yang } \\
\text { dilakukan dengan } \\
\text { tidak tepat }\end{array}$ & \\
\hline 2 & $\begin{array}{l}\text { Tidak } \\
\text { menjelaskan cara }\end{array}$ & Tacit Use \\
\hline
\end{tabular}




\begin{tabular}{|lll}
\hline \multicolumn{5}{c}{} & $\begin{array}{l}\text { penyelesaian } \\
\text { masalah yang } \\
\text { akan digunakan }\end{array}$ & \\
\hline 3 & $\begin{array}{l}\text { Menjelaskan } \\
\text { materi prasyarat }\end{array}$ & \\
& dalam Use \\
& menyelesaikan & \\
& masalah dengan \\
& tidak tepat dan & \\
\hline 4 & tidak lengkap & \\
\hline & Tidak Tacit Use \\
& menjelaskan cara \\
& penyelesaian \\
& masalah yang \\
& akan digunakan & \\
\hline
\end{tabular}

Metakognitif adalah thingking about thinking (Aljaberi \& Gheith, 2015:123). Metakognitif merupakan kemampuan dimana yang menjadi objek berpikirnya adalah proses berpikir yang terjadi pada diri sendiri. Mustafa, Sinaga dan Asmin (2017) juga menyatakan adanya peningkatan kemampuan metakognitif siswa dengan menggunakan perangkat pembelajaran yang dikembangkan berdasarkan pembelajaran berbasis masalah.

Astriani, Surya, dan Syahputra (2017), menyimpulkan bahwa rata-rata kemampuan pemecahan masalah siswa yang diajar melalui pembelajaran berbasis masalah lebih tinggi daripada rata-rata kemampuan pemecahan masalah siswa pada pembelajaran biasa.

\section{KESIMPULAN}

1. Kemampuan metakognitif siswa dalam menyelesaikan masalah matematika dari 24 orang siswa adalah sebagai berikut :

a. Siswa yang berada pada tingkat kemampuan menyelesaikan masalah matematika tinggi berada pada tingkat kemampuan metakognitif Reflective Use dan Strategic Use.

b. Siswa yang berada pada tingkat kemampuan menyelesaikan masalah matematika sedang berada pada tingkat kemampuan Aware Use

c. Siswa yang berada pada tingkat kemampuan menyelesaikan masalah matematika rendah berada pada tingkat kemampuan metakognitif Tacit Use.

2. Kesulitan metakognitif yang dialami siswa dalam menyelesaikan masalah matematika adalah :

a. Kesulitan fakta, yaitu kesulitan dalam memahami penggunaan simbol-simbol matematika dalam menyelesaikan masalah serta kesulitan dalam mempresentasikan simbol-simbol untuk merancang model matematika dari masalah yang diberikan.

b. Kesulitan konsep, yaitu kesulitan dalam mengaplikasikan konsep operasi hitung bilangan bulat dan pecahan untuk menyelesaikan masalah.

c. Kesulitan prinsip, yaitu kesulitan dalam menerapkan aturan-aturan matematika serta kesulitan dalam menghubungkan konsep-konsep yang diberikan untuk menyelesaikan masalah.

d. Kesulitan prosedur, yaitu kesulitan dalam meyajikan langkah-langkah dalam menyelesaikan masalah, serta kesulitan dalam menyusun strategi dalam menyelesaikan masalah secara efektif dan efisien

3. Proses jawaban metakognitif siswa dalam menyelesaikan masalah :

a. Pada saat mengembangkan rencana penyelesaian masalah, siswa menjelaskan materi prasyarat untuk menyelesaikan masalah.

b. Pada saat mengatur atau memonitor penyelesaian masalah, siswa menjelaskan hal yang perlu dilakukan jika tidak memahami masalah yang diberikan, menjelaskan strategi/cara yang digunakan serta meyakini bahwa proses jawaban adalah benar.

c. Pada saat mengevaluasi tindakan penyelesaian, siswa memaparkan alasan tentang pemilihan strategi penyelesaian, siswa memeriksa kembali jawaban yang diperoleh dan menyimpulkan hasil yang diperoleh setelah menyelesaikan masalah.

\section{UCAPAN TERIMA KASIH}

Pada kesempatan ini penulis ingin mengucapkan terima kasih yang tulus dan penghargaan yang setinggi-tingginya kepada semua pihak yang telah membantu penulis dalam menyelesaikan tesis ini dalam waktu yang tepat. Semoga ALLAH yang Maha Kuasa membalas dengan kebaikan yang setimpal. Terima kasih dan penghargaan penulis sampaikan kepada kepada yang mulia dan teristimewa :

1. Bapak Prof. Dr. Bornok Sinaga, M.Pd, selaku dosen pembimbing I dan Bapak Dr. W. Rajagukguk, M.Pd selaku dosen pemimbing II, yang telah meluangkan waktu disela-sela kesibukannya untuk memberikan bimbingan, arahan dan saransaran yang sangat berarti bagi penulis dalam penyusunan tesis ini sampai selesai. 
2. Bapak Prof. Dr. Edi Syahputra, M.Pd dan Bapak Dr. Mulyono, M.Si selaku ketua dan sekretaris Program Studi Pendidikan Matematika Pascasarjana UNIMED.

3. Bapak Prof. Dr. Mukhtar, M.Pd, Prof. Dr. Edi Syahputra, M. Pd dan Dr. H. Banjarnahor, M.Pd selaku narasumber yang telah banyak memberikan masukan pemikiran serta gagasan pada penulis sehingga menambah wawasan pengetahuan penulis dalam penyempurnaan penulisan tesis ini.

4. Bapak Prof. Dr. Bornok Sinaga, M.Pd selaku Direktur Program Pascasarjana UNIMED yang telah memberikan kesempatan serta bantuan administrasi selama pendidikan di Universitas Negeri Medan.

5. Seluruh Bapak dan Ibu Dosen Pendidikan Matematika Program Pascasarjana UNIMED yang telah banyak memberikan ilmu pengetahuan yang sangat berharga bagi pengembangan wawasan keilmuan penulis selama mengikuti studi dan penulisan tesis.

6. Bapak Hendri Dalimunte, M.A selaku staf Prodi Pendidikan Matematika

7. Kepala Sekolah SMP Negeri 4 Bendahara serta Dewan Guru dan staf administrasi yang telah memberikan izin dan kesempatan kepada penulis untuk melakukan penelitian di sekolah tersebut.

8. Secara khusus dan teristimewa penulis mengucapkan terima kasih dan hormat yang setinggi-tingginya kepada orangtua saya Ayah Sulaiman dan Ibu Fatimah berkat izin dan semua kasih sayang, doa, motivasi, jerih payah serta dukungan penuh untuk setiap langkah dalam menyelesaikan perkuliahan dan penulisan tesis ini.

9. Rekan-rekan mahasiswa seperjuangan Program Studi Pendidikan Matematika Program Pascasarjana Universitas Negeri Medan khususnya kelas B-3 angkatan XXIV tahun 2016.

\section{REFERENSI}

Chairani, Z. 2016. Metakognisi siswa dalam pemecahan masalah matematika. Yogyakarta : Deepublish.

National Council of Teachers of Mathematics (NCTM). 2000. Principles and Standards for School Mathematics. Reston. VA: NCTM.

Ormrod, J. 2008. Psikologi Pendidikan Membantu siswa Tumbuh dan Berkembang Edisi keenam. Jakarta : Erlangga.
Fauzi, Kms. 2009. Peranan kemampuan metakognitif dalam pemecahan masalah matematika sekolah dasar. Jurnal kultura, 10(1). pp.1166. ISSN 1411-0229.

Surya, E \& Syahputra, E. 2017. Improving High-Level Thinking Skills by Development of Learning PBL Approach on the Learning Mathematics for

Amalia, E; Surya, E \& Syahputra, E. 2017. The Effectivenessof Using Prob;em Based Learning(PBL) in Mathematics Problem Solving Ability for Junior High School Students. www.ijariie.com. Vol 3, Issue

Napitupulu, E, E. 2011. Pengaruh Pembelajaran Berbasis Masalah Atas Kemampuan Penalaran dan Pemecahan Masalah Matematis Serta Sikap Terhadap Matematika Siswa Sekolah Menengah. Disertasi PPs Universitas Pendidikan Bandung

Astriani, N, Surya, E, Syahputra, E. 2017. The Effect Of Problem Based Learning To Student's Mathematical Problem Solving Ability. International Journal Of Advance Research And Innovative Ideas In Eduation. Vol. 3, Issue-2

Moleong, J. Lexy. 2013. Metodologi Penelitian Kualitatif. Edisi Revisi. Bandung: Remaja Rosda Karya.

Polya, G. 1973. "How to solve $1 \mathrm{t}$ ", $2^{\text {nd }}$ ed. New Jersey : Pricenton University Press.

Sinaga, B. (2017). Development of learning devices through problem based learning model to improve student metacognition skill. Vol 8 no 24. International knowledge sharing platform. www.iiste.org. 